\title{
Pendekatan Inovatif Pengajaran Melalui Pembuatan Media Pembelajaran ELektronika Digital Di Sekolah Menengah Kejuruan
}

\author{
Asnil $^{* 1}$, Fivia Eliza ${ }^{2}$, Irma Husnaini ${ }^{3}$ \\ 123Jurusan Pendidikan Teknik Elektro/Fakultas Teknik/Universitas Negeri Padang \\ *)Corresponding author, $\equiv$ Asnil81@ft.unp.ac.id
}

Revisi 27/06/2019;

Diterima 18/07/2019;

Publish 08/08/2019

\begin{abstract}
Abstrak
Tulisan ini menjelaskan skenario inovatif dalam peningkatan kompetensi mengajar elektronika digital di sekolah menengah kejuruan. Kegiatan ini dilakukan berupa pelatihan dalam mengembangkan media pembelajaran teknik digital khususnya mengenai gerbang logika. Peserta pelatihan bekerja sama dalam tim untuk menyelesaikan topik yang diberikan yang diawali dengan desain dan simulasi yang kemudian melakukan praktek dalam menyelesaikan media pembelajaran yang ditugaskan. Pada akhir skenario dilakukan evaluasi terhadap pekerjaan yang dilakukan dan evaluasi terhadap jalannya kegiatan pelatihan.
\end{abstract}

Kata kunci:

Media pembelajaran, elektronika digital, gerbanglogika

This is an open access article distributed under the Creative Commons Attribution License, which permits unrestricted use, distribution, and reproduction in any medium, provided the original work is properly cited. (C2019 by author(s)

\section{PENDAHULUAN}

\section{Analisis Situasi}

Masa sekarangadalah zaman digital sehingga kantor, industry, lembaga pendidikan, organisasi bisnis sudah berbentuk digitalisasi. Oleh karena itu sebagaian besar disiplin ilmu teknik memasukan elektronika digital merupakan topik wajib dalam kurikulumnya. Tanpa pengetahuan elektronika digital, seorang engginerataupun ilmuwan teknik tidak mungkin merancang dan mengembangkan sebuah system elektronik ataupun pengontrol elektronik ataupun yang dioperasikan dengan sinyal digital, sehingga topik ini adalah tuntutan yang harus dipenuhi pada pendidikan teknik terutama pada abad ke-21(Attarzadeh, F., Gurkan, D., Benhaddou, 2006). Oleh karena itu, topikpembelajaran elektronika digital harus dirancang dan diajarkan sedemikian rupa, sehingga siswa siap untuk menguasai setiap topik yang terkait dengan elektronik digital dengan benar(Choi, S., Saeedifard, 2012).Karena pembelajaran tradisional yang biasa digunakan dengan media papan tulis dan power point hanya akan membuat siswa belajar pasif sehingga tidak menimbulkan minat yang tinggi dari siswa (Wang \& $\mathrm{Hu}, 2017$ )

Belajar adalah kegiatan yang mengarah pada perubahan dan kontrol terhadap apa yang diajarkan, sedangkan mengajar adalah kegiatan praktis atau tindakan, disengaja dan disadari untuk membantu pembelajaran(Bhuyan, Azmiri Khan, \& Rahman, 2018). Guru harus berperan 


\section{Suluah Bendang: Jurnal Ilmiah Pengabdian Kepada Masyarakat}

penting sebagai fasilitator dalam proses belajar mengajar. Pesatnya perkembangan teknologi yang muncul dalam beberapa tahun terakhir telah mengubah cara siswa belajar.Dua unsur penting yang harus diperhatikan oleh seorang guru dalam proses belajar mengajar, yaitu metode yang digunakan dan media pembelajaran yang dipakai. Kedua aspek ini saling berhubungan dimana pemilihan metode tertentu sangat berpengaruh terhadap media yang digunakan. Karena penggunaan media pembelajaran yang merupakan komponen atau wahana fisik yang mengandung materi instruksional yang dapat meransang peserta didik untuk belajar (Arsyad, 2014).

Musyawarah Guru Mata Pelajaran Teknik Audio Video (MGMP TAV) Kabupaten pesisir Selatan merupakan perkumpulan guru-guru Teknik Audio Video yang terdiri dari beberapa sekolah menengah kejuaruan. Diantaranya adalah SMK N 1 Koto XI Tarusan, SMK N 1 Painan, SMK N 1 SUTERA, SMK N 1 Linggo Sari Baganti dan SMK N 1 Ranah Ampek Hulu Tapan. Salah satu tujuannya adalah untuk menyiapkan siswa agar memiliki keterampilan untuk memasuki lapangan kerja terutama pada perusahaan yang bergerak di bidang elektronik selain untuk melanjutkan ke jenjang pendidikan yang lebih tinggi. Salah satu diantara kendala yang dihadapi dalam mewujudkan apa yang menjadi tujuan mereka adalah keterbatasan media pembelajaran yang dapatmembantu dalam meningkatkan pemahaman siswa untuk mempelajari konsep dari teknik digital, selain dari itu pemahaman dalam menggunakan media yang sesuai dengan juga perlu ditingkatkan.

Pengembangan media pembelajaran yang sesuai sangat dibutuhkan karena secara tidak langsung pembelajaran yang dilakukan sangat berefek kepada kegiatan praktek industri (Prakerin) di lapangan. Sebagian besar tempat siswa melaksanakan prakerin adalah perusahaan yang bergerak dibidang elektronik dan digital, seperti PT. Panasonik, Sharp, LG, Samsung dan banyak perusahaan elektronik lainya. Semua perusahaan tersebut bergerak dalam bidang elektronik yang menerapkan system digital, baik untuk proses maupun hasil roduksi. Oleh karena itu, media pembelajaran dan pengetahuan terhadap penggunaan media yang baik dalam proses pembelajaran sangat dibutuhkan sehingga apa yang diajarkan disekolah bisa selaras dengan apa yang akan ditemui oleh siswa di lapangan.

\section{Solusi dan Target}

Berdasarkanuraian yang telah dijelaskan pada analisis situasi, maka perlu diberikan suatu solusi terhadap kendala apa yang sedang dihadapi oleh MGMP TAV SMK kabupaten pesisir selatan. Berdasarkan kesepakatan dengan pengurus dari MGMP TAV Kabupaten Pesisir Selatan maka untuk mengatasi masalah tersebut dilakukan sebuah kegiatan pelatihan mengenai media pembelajaran terutama untuk pembelajaran pratikum teknik digital. Dengan demikian diharapkan pengetahuan mengenai penggunaan media yang sesuai sehingga apa yang diajarkan disekolah bisa sesuai dengan apa yang ditemui dilapangan. Sasaran dari kegiatan ini adalah guru-guru yang tergabung dalam organisasi MGMP TAV kabupaten Pesisir Selatan.

Guru yang menjadi peserta pelatihan diharapakan mampu untuk mengembangkan ide-ide baru dari apa yang sudah diberikan diwaktu pelatihan sehingga masalah-masalah yang ada dalam proses pembelajaran Teknik Digital bisa teratasi dengan baik. Hasil dari kegiatan pelatihan tersebut berupa purwarupa atau modul Teknik Digital yang dapat digunakan untuk kegiatan pratikum dan menjadi dasar untuk pengembangan kegiatan pembelajaran. Dengan demikian, secara tidak langsung pihak sekolah juga terbantu dalam menyediakan sarana yang lebih baik untuk anak didiknya. Untuk merealisasikan kegiatan sesuai dengan permasalahan yang ditemukan seperti yang telah dijelaskan sebelumnya, maka langkah-langkah untuk merealisasikan kegiatan tersebut adalah sebagai berikut; 


\section{Persiapan}

Agar kegiatan dapat berjalan dengan baik sesuai dengan perencanaan, maka dilakukan kegiatan persiapan antara lain;

a. Mengadakan observasi terhadap objek sasaran, hal ini dalukan agar informasi yang diperoleh lebih membeikan gambaran yang jelas terhadap kehiatan yang akan dilakukan.

b. Melakukan pertemuan dan diskusi dengan anggota tim pelaksana pengabdian dalam merumuskan langkah-langkah apa yang harus dilaksanakan dalam kegiatan

c. Penentuan peserta kegiatan

Agar kegiatan berjalan lebih efektif maka jumlah peserta kegiatan pelatihan dalam kegiatan ini ditetapkan sebanyak 15 orang sesuai dengan bidangnya

d. Kegiatan selanjutnya adalah menentukan materi pelatihan yang berhubungan dengan system digital sesuai dengan permasalahan yang ada pada khalayak sasaran.

2. Pelaksanaan Kegiatan

Kegiatan pelatihan dilaksanakan dalam dua scenario; (1) kegiatan pelatihan dalam bentuk pemberian teori yang dilaksanakan dalam bentuk ceramah dan tanya jawab, (2) kegiatan pelatihan dalam bentuk praktek.

3. Evaluasi kegiatan.

Evaluasi dilakukan untuk mengetahui tingkat penyerapan materi dan praktek dari pelaksanaan kegiatan. Hasil dari evaluasi akan menjadi bahan pertimbangan untuk melaksanakan kegiatan lanjutan pada tahun berikutnya.

Pelaksanaan kegiatan dilakukan pada tanggal 1 sampai 4 Oktober 2019 dengan lokasi kegiatan pelaksanaan pelatihan di SMK N 1 SUTERA di Kabupaten Pesisir Selatan. Target yang diharapkan dari kegiatan ini adalah 1) Peningkatan pengetahuan dan keterampilan guru MGMP TAV Kabupaten Pesisir Selatan dalam menggunakan media pembelajaran yang sesuai dengan kebutuhan. Dalam hal ini sesuai dengan kebutuhan guru MGMP TAV Kabupaten Pesisir Selatan adalam media pembelajaran untuk topik teknik digital, 2) Purwarupa media pembelajaran pratikum teknik digital, 3) Guru mampu mengatasi sejumlah kendala dalam pengembangan media pembelajaran.

\section{METODE PELAKSANAAN}

Kegiatan pengabdian dilaksanakan di SMK N 1 SUTERA pada tanggal 1 sampai 4 Oktober 2019 dengan khalayak sasaran adalah guru-guru yang tergabung dalam organisasi Musyawarah Guru Mata Pelajaran Teknik Audio Video (MGMP TAV) Kabupaten Pesisir Selatan. Metode yang digunakan dalam penyampaian materi baik yang bersifat teori maupun praktek adalah sebagai berikut;

1. Metode ceramah dan tanya jawab

Metode ini dipandang sesuai dalam penyampaian materi secara teoritis. Melalui tanya jawab dengan peserta kegiatan, tim pelaksana dapat mengadakan penjajakan mengenai kemampuan awal peserta tentang materi yang disampaikan.

2. Praktek langsung

Setelah mendapatkan pengetahuan secara teoritis maka dilakukan kegiatan praktek langsung membuat media pembelajaran untuk pratikum. Dalam hal ini yang dilakukan adalah merancang atau mendesain sebuah system digital, menghitung kebutuhan komponen yang digunakan, merakit sendiri system digital sesuai dengan yang direncanakan dan melakukan troubledhooting.

Indikator keberhasilan dari kegiatan ini adalah selesainya purwarupa media pembelajaran pratikum untuk mempelajari teknik digital. Evaluasi pelaksanaan kegiatan juga dilakukan deng menggunakan angket untuk melihat persepsi guru sebagai peserta pelatihan terhadap pelaksanaan kegiatan yang dilakukan. 


\section{HASIL DAN PEMBAHASAN}

Kegiatan pengabdian yang dilakukan dapat dikatakan berjalan dengan baik tanpa ada hambatan angberarti. Kegiatan diikuti dengan baik oleh peserta sehingga hasil yang diharapkan dapat tercapai dengan baik.

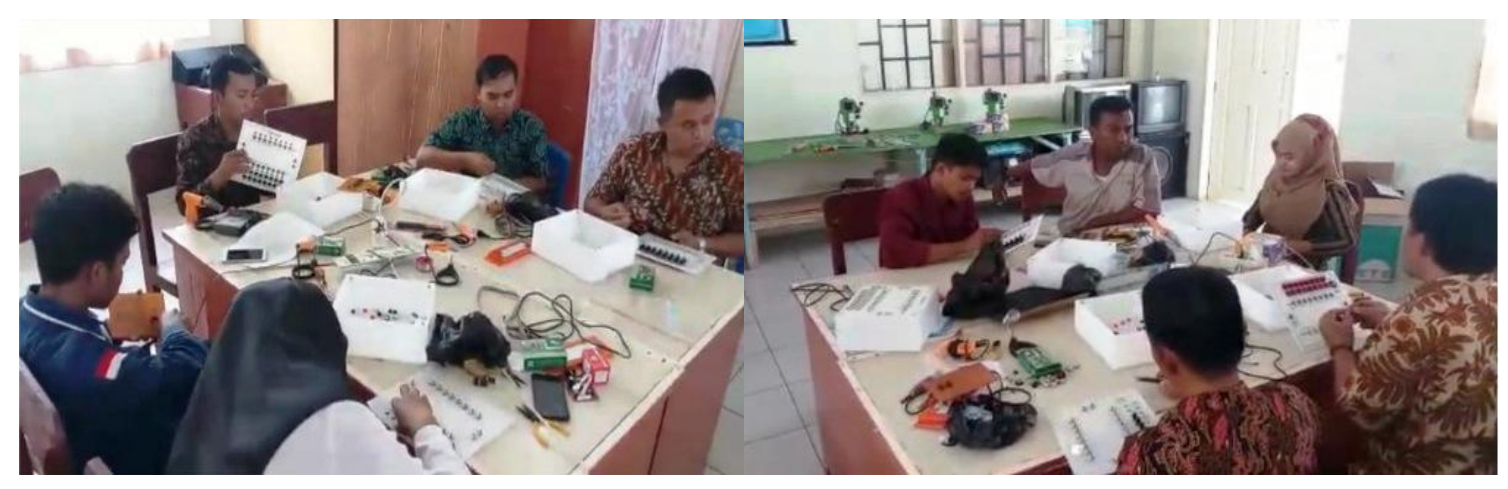

Gambar 1. Kegiatan praktek membuat media pembelajaran pratikum teknik digital

Setelah kegiatan dilaksanakan, tahap selanjutnya adalah melakukan evaluasi dengan melihat persepsi dari guru sebagai peserta pelatihan terhadap kegiatan yang dilakukan. Untuk melihat persepsi dari peserta dilakukan dengan mengisi angket, pada table 1 dapat dilihat hasil dari persepsi guru sebagai peserta pelatihan terhadap kegiatan yang dilakukan.

Tabel 1. Rekapitulasi Persepsi Guru Terhadap kegiatan yang dilaksanakan

\begin{tabular}{|c|l|c|c|}
\hline No & \multicolumn{1}{|c|}{ Indikator } & Skor & \% Skor \\
\hline 1 & Pembelajaran & 61.5 & 82 \\
\hline 2 & Perilaku & 60 & 80 \\
\hline 3 & Reaksi & 60.75 & 81 \\
\hline 4 & Hasil & 60 & 80 \\
\hline \multicolumn{2}{|l|}{ Skor Total } & 60.5625 & 80.75 \\
\hline
\end{tabular}

Berdasarkan tabel 1 dengan merujuk pada skor penilaian secara keseluruhan, maka dapat dilihat bahwa pada indikator pembelajaran menunjukkan peserta merasa setuju sistem pembelajaran yang diselenggarakan pada pelatihan sudah baik, hal ini dapat dilihat dengan skor penilaian mencapai 61.5 yang masuk pada rentang kriteria setuju. Pada indikator perilaku menunjukan hal yang sama yaitu sebagian besar peserta setuju bahwa pelatihan menghasilkan perilaku positif yang sangat mendukung dalam kegiatan dan skor penilaian pada indikator ini mencapai 60. Pada tabel hasil perhitungan diatas dapat kita lihat pula bahwa untuk indikator reaksi dan hasil menunjukan keterangan yang sama yaitu sebagian besar peserta menunjukan persetujuannya terhadap indikator reaksi dan hasil. Skor penilaian untuk indikator reaksi mencapai 60.75 dan indikator hasil mencapai skor nilai 60.

Dari hasil skor penilaian jawaban responden diatas, didapatkan skor tertinggi untuk indikator pembelajaran, dimana diperoleh kisaran skor jawaban sebesar 61.5 atau $82 \%$ peserta setuju bahwa pembelajaran pada pelatihan berjalan dengan baik. Berdasarkan skor keseluruhan untuk semua indikator didapat skor nilai sebesar 60.5625 dan skor nilai tersebut berada pada rentang kriteria setuju. Hal ini menunjukan bahwa peserta cenderung setuju bahwa pelatihan telah berjalan dengan baik.

Berdasarkan penelitian menggunakan frekuensi tabulasi dan perhitungan skor atas indikator pada akhirnya dapat melihat dan mengambil kesimpulan dari keseluruhan indikator 
yang telah dihadirkan adalah persepsi setuju bahwa pelaksanaan pelatihan telah berjalan dengan baik, dimana sebagian besar peserta merespon positif terhadap semua aktivitas maupun fasilitas yang disediakan selama menjalani pelatihan. berdasarkan indikator-indikator yang telah dianalisis dapat dilihat pula bahwa sebagian besar peserta berpandangan bahwa pelaksanaan pelatihan telah memberikan manfaat yang mendalam dan sangat membantu dalam peningkatan kualitas diripeserta.

\section{KESIMPULAN}

Dari kegiatan yang dilakukan sudah terjadi transfer pengetahuan dan teknologi kepada peserta pelatihan terutama mengenai media pembelajaran pratikum berupa purwarupa untuk untuk mempelajari topik teknik digital. Selain dari itu, juga dapat disimpulkan bahwa kegiatan pelaksanaan pelatihan dapat berjalan dengan lancar tanpa hambatan yang berarti serta dari persepsi guru sebagai peserta kegiatan juga mendapat persepsi positif terhadap kegiatan yang dilaksanakan. Luaran pengabdian berupa laporan, artikel yang dimuat di jurnal ber ISSN, berita yang dimuat di media massa yang dalam hal ini menggunakan media nasional yang sudah publish ada tanggal 9 Oktober 2019 serta video kgiatan pelatihan. Dari apa yang sudah dilakukan, tim pelaksana juga mendapat masukan dari peserta agar pelaksanaan kegiatan serupa dapat dilakukan secara berkelanjutan sehingga bias terjalin kerja sama yang baik antara Universitas Negeri Padang dengan masyarakat asaran.

\section{DAFTAR PUSTAKA}

Arsyad, A. (2014). Media Pembelajaran. Jakarta: Rajawali Pers.

Attarzadeh, F., Gurkan, D., Benhaddou, D. (2006). Innovative improvements to engineering technology laboratory education to engage, retain and challenge students of the 21st century. ASEE Gulf-South West Annual Conference. American: American Society for Engineering Education.

Bhuyan, M. H., Azmiri Khan, S. S., \& Rahman, M. Z. (2018). Teaching digital electronics course for electrical engineering students in cognitive domain. International Journal of Learning and Teaching, 10(1), 1. https://doi.org/10.18844/ijlt.v10i1.3140

Choi, S., Saeedifard, M. (2012). An educational laboratory for digital control and rapid prototyping of power electronic circuits. IEEE Transaction on Education, 55(2), 263-270.

Wang, Z., \& Hu, S. (2017). Teaching Reform on Digital Circuit and Logic Design Course. American Journal of Education and Learning, 2(2), 148-152. https://doi.org/10.20448/804.2.2.148.152. 